\title{
From the mouths of students: two illustrations of narrative analysis to under- stand engineering education's ruling relations as gendered and raced
}

\section{Dr. Alice L Pawley, Purdue University, West Lafayette}

Alice L. Pawley is an associate professor in the School of Engineering Education with affiliations with the Women's, Gender and Sexuality Studies Program and Division of Environmental and Ecological Engineering at Purdue University. She has a B.Eng. in chemical engineering (with distinction) from McGill University, and an M.S. and a Ph.D. in industrial and systems engineering with a Ph.D. minor in women's studies from the University of Wisconsin-Madison. She runs the erstwhile Research in Feminist Engineering (RIFE) group, now renamed the Feminist Research in Engineering Education (FREE) group, whose diverse projects and group members are described at the website http://feministengineering.org/. She can be contacted by email at apawley@purdue.edu.

\section{Canek Moises Luna Phillips, Purdue University, West Lafayette}

Canek Phillips is a graduate student in the School of Engineering Education at Purdue University-West Lafayette and works as a graduate assistant in Dr. Alice Pawley's Feminist Research in Engineering Education lab. He holds a B.S. in Mechanical Engineering from Rice University and an M.S. in Mechanical Engineering from Colorado State University. His research is focused on how people relate knowledge in engineering forums. 


\title{
From the mouths of students: Two illustrations of narrative analysis to understand engineering education's ruling relations as gendered and raced
}

\begin{abstract}
Much research done in engineering education on white women and people of color's underrepresentation relies on methods which necessitate collapsing the experiences of all women together and the experiences of all people of color together in order to gain sufficiently large sample populations for statistical tests. This methodologically necessary act functions to erase the experiences of women of color for the purposes of the method, not for the purpose of better understanding the phenomenon, and runs counter to existing social science research on gender and race. With this project, we are working to develop methods that allow us to "learn from small numbers" of students, as this is what we have in the context of undergraduate engineering education. This paper builds on work introduced at ASEE 2013, where we discussed our methodological challenges with data collection and analysis. This current paper describes the analysis decisions we made in the intervening year, and offers two cases to illustrate the affordances of the proffered method to help engineering education researchers think about how the structure of engineering educational institutions - the "ruling relations" by which we structure our undergraduate engineering programs - function to gender and race our undergraduate engineering populations.
\end{abstract}

\section{Introduction}

While white women and most racial minority men and women are still underrepresented in engineering education across the United States and across engineering disciplines compared to their representation in the general population or in college students specifically, the patterns of underrepresentation are different when looking at race and gender together rather than independently. For example, in 2010, white women constituted $16.2 \%$ of all white engineering students, while African American women are $25 \%$ of all African American engineering students. ${ }^{1}$ In fact, of all the races considered underrepresented in engineering education, white women constitute the smallest fraction of their racial group. The theoretical perspective that prompts researchers to methodologically consider race and gender together is called "intersectionality," and has its roots in law, sociology and women's studies. ${ }^{2}$ In addition, much engineering education research on gender and race has tended to take a dated perspective on gender and race: briefly, that gender and race are enduring, unquestionable demographic characteristics of individuals. In contrast, much valuable work elsewhere in the social sciences, particularly in sociology, interprets gender and race as a set of relations and social processes in context, ${ }^{3}$ which allows researchers to consider how institutions and organizations themselves are "gendered" and "raced." "-6 This work is under-engaged by engineering education researchers, but would prompt us to consider that the fact that white men constitute the majority of engineering students, faculty and administrators (let along practitioners) is evidence of the gendered and raced character of engineering educational structures, where the "ruling relations" (which are understood as the operating procedures that implicitly or explicitly govern "how we do things" in engineering education) maintain the institution's gendered and raced character in the face of explicit diversity and inclusion efforts. ${ }^{7}$ It allows us to see why diversity efforts have made such little progress in engineering education so far, compared to the effort and resources invested. 
This research works to answer these questions:

RQ1. How do underrepresented undergraduate engineering students describe their interactions with educational institutions through personal narratives?

RQ2. What institutional factors do these narratives reveal that affect the educational persistence and success of white women and students of color in undergraduate engineering educational institutions?

This paper builds upon work we presented at ASEE 2013 where we described the theoretical and methodological grounding of this project, and expands now into the presentation of data and analysis. ${ }^{8}$ Since that time, we have incorporated theories of intersectionality and gendered and raced ruling relations into the interpretation of our interview data, collected from a diverse set of undergraduate engineering students or recent graduates. We present stories from two students as cases to demonstrate the analytic process which treats the interview intersectionally, and helps us see how ruling relations function to maintain engineering education a gendered and raced institution. We analyze these stories over multiple readings where each reading has a particular lens, in contrast with a process of iterative coding (whether motivated by thematic analysis or grounded theory). These readings make use of narrative theory, a method developed in the social sciences that prompts us to view students' responses as having a structure from which we can also learn - in other words, narrative theory suggest that how students tell us their stories of their engineering education is as important to our research as what they say.

We believe that conference papers should make use of the advantages afforded conference papers over journal papers: the expectation of presenting intermediate conclusions or as-yet unfinished work; the absence of page restrictions so we have the space make available our detailed method for community scrutiny; and the opportunity to discuss findings with colleagues. We have structured this paper in light of these affordances: we discuss in detail this study's developments regarding data handling, analysis and interpretation. We illustrate what we can learn regarding ruling relations from these small numbers of interviews using two cases.

\section{Background}

Key literature from past work

In our 2013 paper, ${ }^{8}$ we discussed at length the foundational literature that guides this work. We will not repeat that there, but present highlights in which to situate this paper, and encourage readers to read the longer work for a deeper treatment.

Briefly, we take race and gender as primary lenses of social analysis. Race is a social categorization of people based on physical and cultural characteristics; its history is rooted in biological essentialism, which we now understand as a categorization scheme wrongly justified not by biology but by colonialism, including slavery and the genocide of indigenous people. ${ }^{9}$ Gender is also a social categorization of people based on a complex of physical characteristics, and also adding in reproductive roles, and additional social relations; noted gender theorist Connell ${ }^{3}$ defines gender as "the structure of social relations that centers on the reproductive arena, and the set of practices that bring reproductive distinctions between bodies into social processes" (p. 11). So, for example, because we see more men than women in our engineering courses, this definition of "gender" means we can infer that we have ordered social relations to make it so. Our study is on the social relations that so order our classrooms. 
Our research aims to take an intersectional approach to the study of gender and race. This means that we note how existing logics of the study of race and gender function to erase the experiences of women of color. Crenshaw ${ }^{2}$ explored this with respect to the experiences of Black women in her germinal piece on discrimination law: she demonstrated through case studies that Black men had come to represent the experiences of all Black people in discrimination cases, and that Black women could not do similarly, and that White women had come to represent all women, but Black women again could not do similarly. She wrote, "sex and race discrimination have come to be defined in terms of the experiences of those who are privileged but for their racial or sexual characteristics." In other words, Black men had come to represent all Black people because they were only "disadvantaged" in terms of race; White women had come to represent all women because they were only "disadvantaged" in terms of sex. But this functions to erase the experiences of Black women, who can be discriminated against based on race, sex, or both together in a different way than both race and sex independently.

In a parallel way in engineering education research, White women have come to represent the experiences of all women of color because there are usually so few women of color the statistical significance of their experiences are insufficiently powerful to be broken out separately. While there may be methodological justification to collapse women of all races together, this act is wholly counter the recommendations of race and gender theory. Intersectionality theory demands that we consider how race and gender act together, and particularly to highlight the experiences of women of color rather than erase them. In this study, therefore, we use methods that have the ability to help us "learn from small numbers" of people.

In addition, while our project initially endeavored to focus on gender and race, as this is how governing bodies frame the underrepresentation problem in engineering education, ${ }^{10}$ we quickly realized that we could not overlook class theory in our analysis. Briefly, class theory undergirds race and gender theory first by virtue of framing the value of considering certain groups "classes" to study, and second by providing conflict theory as a foundation for much anti-racist and feminist social theory. ${ }^{11}$ However, in the United States, we live in a culture that historically bound race and class together through law and policy, including through segregation statues, housing policy, and federal loans for mortgages, and echoes of this history remain firm in contemporary US society. ${ }^{12}$ So, simply speaking, to look at race from an institutional perspective necessitates a study of class because of the processes by which we collectively have raced so many economic practices over the history of the United States.

The final key theoretical concept important to understanding the rest of the paper is that of "ruling relations," a theory advanced first by sociologist Dorothy Smith. ${ }^{7}$ Campbell and Gregor describe the concept: ${ }^{13}$

"Smith saw the benefit of being able to make visible as social relations the complex practices that coordinate people's actions across separations of time and space, often without their conscious knowledge. [...] "Ruling" is the concept that Smith uses to name the sociallyorganized exercise of power that shapes people's actions and their lives. Texts are nearly always implicated in ruling, at least in contemporary societies. Think of how prevalent paper, computers, and information systems are in our own everyday worlds. Texts carry the determinations of many of our actions. [...] However, ruling relations are more than an 
imposition of rules. They rely on people knowing how to take them up and act in an appropriate manner." (pp. 31, 32, 33, emphasis in original).

So, for example, we might consider the ruling relations around an educational institution. Every day, thousands of people know to drive, walk, or take the bus (on predefined routes, with a bus pass or money that allows them to ride the bus) to a university. People classified as "students" know to enter specific buildings at specific times of day, sit in specific rooms, with notebooks or computers out to take notes on what someone at the front of the class speaks out loud. People classified as "instructors" know to come to those same buildings and rooms at particular times, and to talk to a group of people already there about a particular specific topic. We could discuss the work that other classes of people come to a university to carry out. But all this work is coordinated in some way - together, everyone knows what they are doing on campus, and how they can expect others to behave. Smith argues that this work is usually coordinated by different texts - operating procedures of the organization. So, in this example, there are policies that govern how classes operate, or what rights people classified as "students" have to certain kinds of information, there are bulletins (mostly electronic now) that list the available classes at different times of day for a given "semester," there are syllabi that govern the procedures by which a particular course (and all the people therein) will operate. There are even the social agreements we have around what constitutes "money" or the representation of money through a "bus pass," and someone entering a bus at a particular time knows the bus will follow a proscribed route along a particular schedule. Texts govern so many of our social relations they recede into the background of our work.

But these governing texts have to be written, and are written by people in power. Campbell and Gregor develop this idea: "Smith uses the notion of ruling as a way of understanding how power is exercised in local settings to accomplish extra-local interests. Ruling takes places when the interests of those who rule dominate the actions of those in local settings." (p. 36) So the texts that coordinate and organize the work of people in a university were written by those more "central" to the university to coordinate the work of people on the edges - so, for example, a university senate might determine certain policies that govern the behavior of faculty (only a small subset of whom are in the senate) or students. But for those policies to function, both faculty and students must agree to be governed by them, and must choose to act in a way proscribed by the policy (usually there are organizational-level consequences should they choose otherwise). These policies may sometimes have multiple logics at work, prompting people to operate in ways at odds to their own interests. For example, we could consider grades (a type of text used by the university to represent students' accomplishments to others ${ }^{14}$ ) to sometimes get in the way of students' learning, as they become externally motivated by a grade and not intrinsically motivated to learn the material, which could have helped them to better learn the material.

In concert with the literature on gender and race, Smith's work on ruling relations would recommend looking at students' experiences of coordinated social relations to better understand how the institutions in which those social relations are situated may be gendered and raced - that is, how the experience of the institution differs across genders and races.

We next turn to different components of our methodology, or the theoretical foundation of our methods. 


\section{Narrative theory}

We draw on three approaches to narrative theory for this work.

Polkinghorne ${ }^{15}$ outlines the multiple ways that "narrative" is used in qualitative analyses. $\mathrm{He}$ describes a narrative as any text (such as an interview transcript) "that [is] thematically organized by plots" (p. 5) and differentiates the "analysis of narratives" from the use of "narrative analysis." The former is the analysis of data that is in the form of narrative ("prosaic discourse," in contrast with "poetic discourse," p. 6) but may be analyzed using any qualitative method, while the latter is a type of analysis which uses narrative form as analytic lens. Polkinghorne notes that people make sense of their lives through narrative, or story, and that therefore it may be useful to organize interview text into a story-like narrative because stories help people share their own perception of reality in the context of their own lives.

Polkinghorne describes two types of knowledge embodied into stories: a "paradigmatic cognition" which he defines as "classifying a particular instance as belonging to a category or concept" (p. 9); and "narrative cognition [that] configures the diverse elements of a particular action into a unified whole in which each element is connected to the central purpose of the action," (p. 11). These two types of knowledge can be treated as analytic processes, where a paradigmatic analysis "seeks to locate common themes or conceptual manifestations among the stories collected as data" (p. 14; grounded theory is a type of paradigmatic analysis) while a narrative analysis "synthesizes or configures events into an explanation of, for example [...] how an individual made a career choice." (p. 16) So narrative analysis "is the procedure through which the researcher organizes the data elements into a coherent developmental account," (p. 15) producing a narrative as the research result through various processes including "narrative smoothing," the exclusion of portions of the story that the analyst judges not relevant to the research result. This production of a narrative as a analytical outcome, Polkinghorne argued, helps readers learn from as well as develop empathy for the participant:

"Hearing a storied description about a person's movement through a life episode touches us in such a way as to evoke emotions such as sympathy, anger, or sadness. Narrative cognition gives us explanatory knowledge of why a person acted as he or she did; it makes another's action, as well as our own, understandable... The cumulative effect of narrative reasoning is a collection of individual cases in which thought moves from case to case instead of from case to generalization." (p. 11)

Polkinghorne uses Dollard's criteria for life histories ${ }^{16}$ to develop his own set of criteria for a storied narrative, ${ }^{15}$ which should:

1. give "cultural context in which storied case study takes place"; (p. 16)

2. "attend to embodied nature of the protagonist," (p. 17)

3. consider "the general cultural environment and person as embodied, but also importance of significant other people affecting actions and goals of protagonist;" ( $p$. 17)

4. outline a "story [...] about central character and movement towards outcome;" (p. 17)

5. "consider historical continuity of characters;" (p. 17)

6. "generate a story in a bounded temporal period," with "a beginning middle and end;" (p. 17) 
7. "must make generation of the researched occurrence plausible and understandable" (p. 18)

These criteria center the creation of a narrative on creating a setting with depth, temporal continuity, and order that should connect to the reader in an easily translatable way.

We draw also on Mauthner \& Doucet's "voice-centered" method ${ }^{17}$ to make visible otherwise hidden social relations. In this method, a researcher goes through multiple different readings of an interview transcript, each time attending to a different type of "voice," noticing how the story is told as well as what is said. Mauthner \& Doucet proposed conducting four specific readings of a transcript:

- Reading 1: The researcher reads the data for the overall plot and story with attention paid to respondent's identification of critical developments, important characters, and side stories. (p. 126)

- Reading 2: The researcher focuses their attention on the way the speaker feels and speaks about herself. The researcher studies how and when the speaker used the active voice, in what situations, with whom, and furthermore, when the active voice shifted to a passive one.

The goal is to see "how she speaks of herself before we speak of her." (p. 128)

- Reading 3: The investigator studies the "interpersonal relationships" in the speaker's life by identifying how the respondent spoke about the relationships within their homes and workplaces to both people and institutions. (p. 131)

- Reading 4: The researcher codes for the macro-structures in the life of the respondent, i.e. the disembodied social, political, and cultural forces that reify themselves in the life of the speaker through the critical developments and nature of relationships in the speaker's story. When all the readings are taken together, Mauthner \& Doucet's voice-centered approach allows for sociological analysis without neglecting either the co-construction of the interview made through the prompts of the interview questions, or the voice of the respondent.

Finally, we also draw on the work by Clair and colleagues. ${ }^{18}$ Here, the authors deliberated the merits of different narrative approaches as pedagogical tools to teach others unfamiliar with types of experiences. Clair and colleagues discuss three approaches:

- "Personal narratives:" Clair and colleagues called this the "articulation" of one's own story, and characterized it with having the strength of an unfiltered authenticity. But a speaker telling her/his own story must also face an opposition of non-believers, ridicule, and the consequences of speaking out in such a personal way.

- "The Case Study:" Clair and colleagues offer the case study as a way to shift negative attention away from the speaker in the re-telling of painful stories where "speaking out" might require the reliving of a traumatic event. The authors listed one of the strengths of the case study as being able to engage the insights of the researcher to augment the voice of the speaker, adding to the depth of the story. But the case study approach means that the speaker's voice is no longer the main constructor of the narrative, and a researcher must make sure that she does not dilute the speaker's voice with her own.

- "The Collective Story:" Clair and colleagues describe this type of story as using a method that could be used to tell the experience of a "social category rather than by telling a particular individual's story." (p. 250) The authors characterized the strength of the collective story as being able to convey a painful experience in an anonymous way, but again at the cost of authenticity that connects the speaker to the individuals whose stories are collectivized. 
Clair and colleagues' critiques focus attention toward what a researcher wants their audience to take away from the stories they listen to, asking the researcher whether is it the story, or the person that lived the story that is most important.

We connected each of these methodological perspectives into narrative inquiry into our analytical process, outlined in a later section. These perspectives undergird what we are looking for, and, to some extent, how we look for it. We turn now to a process-oriented framework that has helped us create an analytical method to produce strong claims with high qualitative validity.

\section{Conducting high quality interpretive inquiry}

Walther and colleagues ${ }^{19}$ have developed a typology to help improve the quality of interpretive research in engineering education. They break the analytical tasks into two primary categories of analysis inspired by a metaphor of Total Quality Management: "making the data" and "handling the data." For each of these categories of tasks, there are a variety of types of validity to consider; we reproduce below the majority of what they call their Qualifying Qualitative Research Quality $\left(Q^{3}\right)$ typology.

Table 1: $Q^{3}$ Typology of Quality Settings, taken from Walther et al. (2013, p. 640, Table 1)

\begin{tabular}{|c|c|c|}
\hline Description & Making the data & Handling the data \\
\hline $\begin{array}{l}\text { Validation: How can we improve } \\
\text { the research findings' capacity to } \\
\text { appropriately capture and } \\
\text { represent aspects of the social } \\
\text { reality observed? }\end{array}$ & $\begin{array}{l}\text { Do we get to see what we think we } \\
\text { see? }\end{array}$ & $\begin{array}{l}\text { Is the researcher's version } \\
\text { grounded in the versions of the } \\
\text { participants'? Do we call things by } \\
\text { the right names? }\end{array}$ \\
\hline $\begin{array}{l}\text { Theoretical validation: Do the } \\
\text { concepts and relationships of the } \\
\text { theory appropriately correspond } \\
\text { to the social reality under } \\
\text { investigation? }\end{array}$ & $\begin{array}{l}\text { The research process needs to be } \\
\text { able to capture the full extent of the } \\
\text { social reality studied. }\end{array}$ & $\begin{array}{l}\text { Interpretations need to reflect the } \\
\text { coherence and complexity of the } \\
\text { social reality under investigation. }\end{array}$ \\
\hline $\begin{array}{l}\text { Procedural validation: Which } \\
\text { features of the research design } \\
\text { improve the fit between reality } \\
\text { and the theory generated? }\end{array}$ & $\begin{array}{l}\text { Strategies need to be implemented } \\
\text { in the research design to mitigate } \\
\text { threats to contextual validation. }\end{array}$ & $\begin{array}{l}\text { Processes need to be implemented } \\
\text { to mitigate risks of mis- } \\
\text { constructing the participants' } \\
\text { reality in the researcher's } \\
\text { interpretations. }\end{array}$ \\
\hline $\begin{array}{l}\text { Communicative validation: Is the } \\
\text { knowledge socially constructed } \\
\text { within the relevant } \\
\text { communication community? }\end{array}$ & $\begin{array}{l}\text { The data gathering needs to capture } \\
\text { the respondents' inter-subjective } \\
\text { reality. }\end{array}$ & $\begin{array}{l}\text { The researcher's abstract } \\
\text { interpretations need to be grounded } \\
\text { in the accounts of the participants. } \\
\text { The knowledge produced needs to } \\
\text { be represented in accordance with } \\
\text { the meaning conventions of the } \\
\text { research community. }\end{array}$ \\
\hline $\begin{array}{l}\text { Pragmatic validation: Do the } \\
\text { concepts and knowledge claims } \\
\text { withstand exposure to the reality } \\
\text { investigated? }\end{array}$ & $\begin{array}{l}\text { The concepts underlying the } \\
\text { research design need to be } \\
\text { compatible with reality in the field. }\end{array}$ & $\begin{array}{l}\text { The knowledge produced needs to } \\
\text { be meaningful in the social context } \\
\text { under investigation. }\end{array}$ \\
\hline $\begin{array}{l}\text { Process reliability: How can the } \\
\text { research process be made as } \\
\text { independent as possible from } \\
\text { random influences? }\end{array}$ & $\begin{array}{l}\text { The data needs to be collected and } \\
\text { recorded in a dependable way. }\end{array}$ & $\begin{array}{l}\text { Procedures for generating and } \\
\text { representing knowledge need to be } \\
\text { established and documented. }\end{array}$ \\
\hline
\end{tabular}


One of this paper's authors participated in a $\mathrm{Q}^{3}$ workshop in 2013 organized around this typology to discuss its merits and weaknesses, and attempt to put it into practice in our own research contexts. The workshop hinged on the concept of a "quality plan," which, together with the TQM focus on improving quality through the process of the research, asked participants to reflect on these aspects:

1. Outline the project and method we are considering or using

2. Sketch out the design along the process model of "making the data" and "handling the data."

3. Consider, what aspect of quality are we most concerned with?

For this paper, the answer to the last question is most salient (as the others have already been treated), and consisted of three concerns: first, of doing high quality data analysis when the two analysts had widely variable analytical expertise; second, of conducting interviews in such a way that the open protocol would allow us to answer our research question; and third, that the analysis respected the integrity of the stories participants shared with us.

We then applied our reflection to each of the TQM phases. For example, in the "making the data" phase, we developed the reflection questions outlined in Table 2, and then developed a plan to address them.

\section{Table 2: Quality Plan for making the data}

\begin{tabular}{|c|c|c|}
\hline $\begin{array}{l}\text { Making the } \\
\text { data phase }\end{array}$ & Reflection questions & Process plan to address \\
\hline Recruiting & $\begin{array}{l}\text { How do we make sure we interview the "right" } \\
\text { people? "Right" in terms of our explicit } \\
\text { criteria (people who identify as white women, } \\
\text { or women and men who identify as Black/ } \\
\text { African American, Latino/ Latina, } \\
\text { Native/indigenous or multiethnic) but also } \\
\text { "right" in terms of wanting to understand } \\
\text { institutional structure through their stories }\end{array}$ & $\begin{array}{l}\text { Ask participants for self-identification of } \\
\text { gender and race both in recruitment phase } \\
\text { and interview phase } \\
\text { Diversify interview pool not only with } \\
\text { respect to gender and race but social class, } \\
\text { college class (year in school) and other } \\
\text { theoretically salient characteristics }\end{array}$ \\
\hline Interviewing & $\begin{array}{l}\text { Do the participants tell us (the researchers) } \\
\text { anything "useful" (in terms of us answering } \\
\text { our research questions) through their stories, } \\
\text { based on their goals and our prompts? }\end{array}$ & $\begin{array}{l}\text { Document rationales for choosing follow- } \\
\text { up questions both during data collection } \\
\text { and after; } \\
\text { Articulate concerns or other thoughts about } \\
\text { the data through systematic notes (during } \\
\text { the interview) or memos; use these } \\
\text { thoughts to influence who next to } \\
\text { interview; } \\
\text { Develop a firm grasp of the theory } \\
\text { associated with ruling relations to be able } \\
\text { to ask appropriate follow-up questions in } \\
\text { situ }\end{array}$ \\
\hline $\begin{array}{l}\text { Processing } \\
\text { data }\end{array}$ & $\begin{array}{l}\text { Did we collect and transcribe the stories } \\
\text { accurately? Did participants report their } \\
\text { perceptions as they desired? }\end{array}$ & $\begin{array}{l}\text { - Correct transcripts while re-listening to } \\
\text { interviews } \\
\text { Request participants read through and } \\
\text { correct, change, or otherwise comment on } \\
\text { what they said. }\end{array}$ \\
\hline
\end{tabular}


In terms of "handling the data," we first offer a description of our analytical process, then demonstrate how map it to the $\mathrm{Q}^{3}$ typology.

\section{Method}

\section{Summary of data collection}

Our data collection processes and methodological choices are exhaustively detailed in our 2013

ASEE paper. ${ }^{8}$ Briefly, we recruited current undergraduate engineering students or students within 6 months of graduating who identified as Black or African American, Latino/Latina, Native, or multiracial, or who identified as white women. We interviewed them either at the conference at which we recruited them, or by Skype. Each interview was geared to take approximately 90 minutes, although ended up being variation around this timing. The interview was fairly unstructured, using the initial prompt of "How did you get to be where you are?" so that participants could largely tell their own story the way they wanted. Additional prompts when needed followed a life history structure. Participants chose whether they wanted to be pseudonymized or not, and for the former choice, they chose their pseudonyms (which allows us to avoid the problem of whether to choose raced or gendered pseudonyms). We have decided not to make public whether a participant wanted a pseudonym or not. People who participants referred to by name were always pseudonymized, as we did not have their permission to use their names in our research. We paid participants $\$ 30$ cash (when the interview was in person) or a $\$ 30$ gift card to Amazon.com (when the interview was done by Skype). A professional transcriber transcribed the interviews; we checked the transcripts against the recordings for accuracy, and pseudonymized them as needed. Participants were invited to review the transcripts, and for those who sent us corrections or concerns we made all the changes requested.

\section{Participants}

So far in this study, we have interviewed 12 participants as study subjects. Their names or pseudonyms, demographic information and school at which they were earning or had recently (at the time of the interview) earned their undergraduate engineering degree are reported in Table 3.

Table 3: Participants' demographic information

\begin{tabular}{|l|l|l|l|l|}
\hline $\begin{array}{l}\text { Name/ } \\
\text { pseudonym }\end{array}$ & $\begin{array}{l}\text { Gender } \\
\text { (self-report) }\end{array}$ & Race/ethnicity (self-report) & School & Age \\
\hline Andrew & Male & Black, African American & Howard University & 21 \\
\hline Chelsea & Female & African American & North Carolina State & 21 \\
\hline Jasmine & Female & $\begin{array}{l}\text { Non-Latino, Black/African American, } \\
\text { American Citizen }\end{array}$ & Morgan State & 19 \\
\hline Mariah & Female & Native American & Columbia University & 19 \\
\hline Moises & Male & $\begin{array}{l}\text { African American, } \\
\text { Haitian American }\end{array}$ & Virginia Tech & 22 \\
\hline Nathan & Male & African American & University of Pittsburgh & 22 \\
\hline Sammie & Male & Black or African American & University of Alaska-Fairbanks & 25 \\
\hline Sekerema & Female & Black & Reputable State University & 22 \\
\hline Tristin & Female & Diné & Columbia University & 21 \\
\hline Tyson & Male & Black & Howard University & 20 \\
\hline Vera & Female & African American & University of Texas-Austin & 22 \\
\hline Xuan & Female & Vietnamese (mixed race) & DeVry University & 35 \\
\hline
\end{tabular}

However, we have come to understand how extensively the interviewer and analyst are also "participants" in the research. Our race, class and gender inform the lenses we use to initially 
elicit and then subsequently interpret our study subjects' stories. As a result, we find it necessary to report a short biography on each person who has in some way "shaped" the data and interpretation we report from this project.

Alice is a 37-year-old White woman, an American citizen from Madison, WI, who is currently a faculty member at Purdue University in Engineering Education. Her immediate family (mother, father, both US immigrants, and two siblings born in the US) has four professors and a nurse to its name; her extended family is Canadian and British, and two generations back was either in the coalmines of northern England or the performing arts outside London. She is married, with a White male partner who also has a $\mathrm{PhD}$, and they have a young child together. She therefore currently considers herself upper-middle class, with three degrees in engineering and a professional monthly salary from her tenured position. She shaped the study itself, and applied for the grant money to conduct the study. She conducted all the interviews for this project so far, completed half the analysis reported here, and wrote most of the paper itself. She has some expertise in race, class and gender theory - more than many others doing engineering education research, but not as much as those in sociology, women's studies or other social sciences fields.

Canek is a 30-year-old mixed race man, who identifies himself as mestizo, a term which indicates that he is White and amerindian, and also carries with it the connotation that he comes from Latin American heritage. Canek's background straddles racial and class boundaries, his mother is an amerindian woman from Veracruz, Mexico, and his father is a White man from Los Angeles, California. Canek is a graduate student at Purdue University in the School of Engineering Education, in the process of completing now his tenth-year of post-secondary education, following a similar career pathway as his father who is now a professor, while his mother, a working-class woman is struggling to get a high school diploma. Canek considers himself working-class at the moment, but thinks that he will be able to transition into the middleclass when he graduates from school. Canek's role on the project has been as a research assistant, beginning with a minimal role performing literature reviews, but has grown to the analysis of interview data. Canek's race, class, and gender theory background is intermediate compared to others who specialize in the field, but higher than many of others in the engineering education field.

\section{Analysis}

In our 2013 paper, we explored potential ways to treat interview transcripts from this study holistically, as an initial treatment of transcripts with coding (as planned through the grant proposal) seemed to cause the stories and emotion within each to crumble into pieces. With the help of connections made at ASEE 2013, and informed by the $\mathrm{Q}^{3}$ workshop and typology discussed earlier, we have adopted a multi-step analytic process outlined in Table 4 . So far, because we anticipated that the cases may be divergent rather than convergent, and considering our methodological commitment from learning from small numbers, we intended that each participant's interview be analyzed independently from each other, and we needed to construct a method that would allow us to learn from each case independently rather from the overlap of them all together. However, as we progress through this analysis, we acknowledge that we may find a case-level analytical step helpful where we take the case summaries from all the participants' interviews and look at what we can learn from them all together. 
Our biggest insight from our methodological frameworks is how we needed to be particularly intentional on explicitly reflecting how our race, class and gender (RCG) influence what data we find relevant, what insights we gain from these data, and how we think they relate to the theoretical frame of ruling relations. This seemed true not only for each analytical step, but also for the data collection step, recognizing that the interviewer's RCG influences the questions she asks, the way she follows up on certain parts of the story and not others, and the decision to forsake one line of questions for another. This aspect of data analysis - that the data collection frames the analysis through the identity of the interviewer (or, in cases with more rigid interview protocols, that of the protocol designer) - while acknowledged in the qualitative method

literature, ${ }^{15,17,20-22}$ has remained opaque in much published engineering education research.

We also have come to recognize through our initial analyses, as others have done e.g.21-23 $^{\text {that our }}$ interviews with participants are also not simply transparent windows that let us see the Truth of participants' lives. Participants had stories they wanted to tell us, stories they were willing to tell us, and undoubtedly stories they did not tell us. The interviews, therefore, are participants' stories, as they have approved them as representing them, but they are also research objects, a coproduced dialogue between study subject and interviewer, and would have been different had either participant been a different person or at a different time.

Returning to Walther and colleagues' process-oriented $\mathrm{Q}^{3}$ typology ${ }^{19}$ and our nascent quality plan, in the "handling the data" phase, we are reflecting on these two ideas:

- How do we make sure we don't get fixated on one "exciting" bit of data to the detriment of the rest?

- How do we treat the stories with integrity rather than chop them up into little bits?

We developed our analytical process based on these questions and concepts that we are using this paper to demonstrate. Table 5 illustrates how we currently map our analysis steps to the typology to reduce threats to qualitative validity.

\section{Results}

In this section, we provide the culmination of our first eight analytical steps in the form of case analyses for two participants: "Sekerema," (Table 6) a Black woman in her fourth year of an electrical engineering degree; and "Sammie," (Table 7) a Black man in his junior year of a mechanical engineering degree. These case descriptions come from step 8 of the analytic process, and conform to Polkinghorne's ${ }^{15}$ descriptions of "storied case studies." However, they are informed by all the previous steps, including by the extensive memoing process. We present each case, and then offer some thoughts as to what the case allows us to see that may have been more difficult to see had we adopted a more conventional thematic or coding analytic process. 
Table 4: Analytical steps for this study

\begin{tabular}{|c|c|c|}
\hline \# & Step name & Description \\
\hline 1. & $\begin{array}{l}\text { Interviewer summary } \\
\text { reflection. (Word doc) }\end{array}$ & How did my RCG structure my questions, interactions with the participant? \\
\hline 2. & $\begin{array}{l}\text { Map out the story (Word } \\
\text { doc) }\end{array}$ & $\begin{array}{l}\text { A. Table of contents, label "sidebars" conversations (that don't seem } \\
\text { relevant to the primary discussion). } \\
\text { B. List the "characters," create a map of the characters' relationships. } \\
\text { Memo: how does this help us think about answering our research questions? }\end{array}$ \\
\hline 3. & $\begin{array}{l}\text { Memo on Race/Class } \\
\text { /Gender (RCG) lenses } \\
\text { (Word doc) }\end{array}$ & $\begin{array}{l}\text { Consider: } \\
\text { A. how is my RCG (including intersectionally) operating here? } \\
\text { B. how is RCG (including interjectionally) operating here? }\end{array}$ \\
\hline 4. & Ruling relations (Dedoose) & $\begin{array}{l}\text { What meso (institution-level) and macro-level (race, gender) relations are } \\
\text { operating here? } \\
\text { Memo: how does this help us think about answering our research questions? }\end{array}$ \\
\hline 5. & $\begin{array}{l}\text { Memo on RCG lenses } \\
\text { (Word doc) }\end{array}$ & $\begin{array}{l}\text { Consider: } \\
\text { A. how is my RCG (including intersectionally) operating here? } \\
\text { B. how is RCG (including interjectionally) operating here? }\end{array}$ \\
\hline 6. & $\begin{array}{l}\text { Narrative analysis (Word } \\
\text { doc, labeled with } \\
\text { comments) }\end{array}$ & $\begin{array}{l}\text { A. Trace the voice, including passive/active, "I"/ "You"/ "They" and other } \\
\text { voices; then reflect and memo. } \\
\text { B. Consider how the sidebars identified in step } 1 \text { also bring meaning to the } \\
\text { analysis? Reflect and memo. } \\
\text { C. How does the participant talk about engineering (narratives)? Reflect } \\
\text { and memo. } \\
\text { Memo: how does this help us think about answering our research questions? }\end{array}$ \\
\hline 7. & $\begin{array}{l}\text { Memo on RCG lenses } \\
\text { (Word doc) }\end{array}$ & $\begin{array}{l}\text { Consider: } \\
\text { A. how is my RCG (including intersectionally) operating here? } \\
\text { B. how is RCG (including interjectionally) operating here? }\end{array}$ \\
\hline 8. & Write the case (Word doc) & $\begin{array}{l}\text { Of what is this a case? Write up short case of interview using insights from } \\
\text { passes, memos (especially the ruling relations memos (step 4) and the TOC } \\
\text { (step 1)). The case needs to meet Polkinghorne's criteria for storied cases, } \\
\text { described earlier in this paper. } \\
\text { Then memo: how does this help us think about answering our research } \\
\text { questions? }\end{array}$ \\
\hline 9. & $\begin{array}{l}\text { Interrogate case and other } \\
\text { analyses to answer research } \\
\text { questions. }\end{array}$ & $\begin{array}{l}\text { Present case and other analysis documents to the other analyst, present } \\
\text { claims to public through conference paper and presentation for scrutiny and } \\
\text { interrogation. }\end{array}$ \\
\hline
\end{tabular}


Table 5: Analysis steps mapped to Walther et al.'s $Q^{3}$ typology

\begin{tabular}{|c|c|c|}
\hline Description & Making the data & Handling the data \\
\hline $\begin{array}{l}\text { Validation: How can we improve } \\
\text { the research findings' capacity to } \\
\text { appropriately capture and } \\
\text { represent aspects of the social } \\
\text { reality observed? }\end{array}$ & $\begin{array}{l}\text { We present data collection method } \\
\text { for collective scrutiny by } \\
\text { colleagues and research } \\
\text { community. (Step 9) }\end{array}$ & $\begin{array}{l}\text { We document research insights } \\
\text { mapped to analytical step. (Memo } \\
\text { steps.) }\end{array}$ \\
\hline $\begin{array}{l}\text { Theoretical validation: Do the } \\
\text { concepts and relationships of the } \\
\text { theory appropriately correspond } \\
\text { to the social reality under } \\
\text { investigation? }\end{array}$ & $\begin{array}{l}\text { We have designed the interview } \\
\text { protocol to facilitate inquiry into } \\
\text { the concept of ruling relations. } \\
\text { (Step 4) }\end{array}$ & $\begin{array}{l}\text { We regularly return to the } \\
\text { theoretical framework to see how } \\
\text { we might situate our data (memo } \\
\text { steps); we describe our } \\
\text { understanding of the theory and our } \\
\text { data and their alignment to others } \\
\text { to see whether our interpretation } \\
\text { withstands scrutiny (this paper). }\end{array}$ \\
\hline $\begin{array}{l}\text { Procedural validation: Which } \\
\text { features of the research design } \\
\text { improve the fit between reality } \\
\text { and the theory generated? }\end{array}$ & $\begin{array}{l}\text { We have built memoing and } \\
\text { reflection on the data collection } \\
\text { based on the interviewer's RCG } \\
\text { lenses into the analytic process } \\
\text { (each step) }\end{array}$ & $\begin{array}{l}\text { We are contemplating asking } \\
\text { participants to review the case } \\
\text { analyses. This is not yet part of our } \\
\text { process. } \\
\text { We have built systematic memoing } \\
\text { into the analytic process. }\end{array}$ \\
\hline $\begin{array}{l}\text { Communicative validation: Is the } \\
\text { knowledge socially constructed } \\
\text { within the relevant } \\
\text { communication community? }\end{array}$ & $\begin{array}{l}\text { We have situated our method } \\
\text { within a theoretical framework } \\
\text { recognized as valuable by multiple } \\
\text { research communities. }\end{array}$ & $\begin{array}{l}\text { Our process requires we connect } \\
\text { our claims to our direct readings of } \\
\text { our transcripts, which have been } \\
\text { approved by participants. We will } \\
\text { write papers about our claims that } \\
\text { offer evidence we use to argue each } \\
\text { claim, and present these arguments } \\
\text { with evidence to multiple research } \\
\text { communities for scrutiny. }\end{array}$ \\
\hline $\begin{array}{l}\text { Pragmatic validation: Do the } \\
\text { concepts and knowledge claims } \\
\text { withstand exposure to the reality } \\
\text { investigated? }\end{array}$ & $\begin{array}{l}\text { We set aside } 90 \text { minutes for each } \\
\text { interview, and started each } \\
\text { interview with the question "How } \\
\text { did you get to be where you are?" } \\
\text { Guided by our protocol informed } \\
\text { by our theoretical framework of } \\
\text { ruling relations, we found } \\
\text { participants engaged with the } \\
\text { questions, told authentic stories that } \\
\text { the research team found value in in } \\
\text { our research context. }\end{array}$ & $\begin{array}{l}\text { We intend to present our research } \\
\text { results to a variety of communities, } \\
\text { including educators, administrators, } \\
\text { researchers, and members of the } \\
\text { racial and gender groups from } \\
\text { whom we collected stories. (Step } \\
\text { 9). Whether the stories "hold up to } \\
\text { reality" in these contexts will be a } \\
\text { measure of pragmatic validation. } \\
\text { We will be looking to see whether } \\
\text { the stories evoke emotions in the } \\
\text { audiences, whether audiences can } \\
\text { indeed "learn from small numbers." }\end{array}$ \\
\hline $\begin{array}{l}\text { Process reliability: How can the } \\
\text { research process be made as } \\
\text { independent as possible from } \\
\text { random influences? }\end{array}$ & $\begin{array}{l}\text { We have developed and now } \\
\text { follow standard operating } \\
\text { procedures for data collection and } \\
\text { transcription for consistency. } \\
\text { Our interview procedures are built } \\
\text { on traditional interview practices, } \\
\text { follow a standard procedure, have } \\
\text { been and continue to be publically } \\
\text { discussed, and were approved by } \\
\text { our IRB office. }\end{array}$ & $\begin{array}{l}\text { We have documented and } \\
\text { published our analytic processes } \\
\text { both to stay consistent and for } \\
\text { scrutiny by colleagues and the } \\
\text { research community (this paper). }\end{array}$ \\
\hline
\end{tabular}


Table 6: Case analysis of Sekerema

Sekerema is a 22-year-old Black woman originally from Houston, TX attending Reputable State University. She is currently a fourth-year student studying electrical engineering, which she financed with the help of federal grant monies and assistance from her father. But Sekerema's father's role in her story is more than financial: he served as her childhood inspiration to become an engineer. Now, his hopes, along with those of her mother's - that engineering will provide Sekerema with a financially secure future - factor strongly into Sakerema's morality. As you will read, Sekerema's morality constantly confronts her with selfdoubt as she goes through the trials and tribulations of her engineering education.

From an early age, Sekerema wanted to be in science or engineering. She grew up in a loving family in a middle class suburb. Her father provided the majority of the income while working as a petroleum engineer, and her mother worked as well as a schoolteacher. Sekerema also had two other sisters, one studying to become a lawyer, and the other a senior in high school. All three sisters were set to graduate the following year.

Sekerema's parents both immigrated from Nigeria, and perhaps because of a past experience in Nigeria they worked to instill an ethic in Sekerema and her sisters that being able to support one's self as an adult was paramount. Sekerema's parents saw college as a means to an end, a way for someone to acquire skills to enter into a good-paying profession and "put food on the table." They instilled this idea into Sekerema because they loved her and wanted her to avoid the hardships of poverty.

As Sekerema matured from childhood into adulthood, her interests diversified as well. Sekerema originally had wanted to be a scientist or engineer because she wanted to follow in her father's footsteps; he, by just being an engineer, had made the idea seem cool to his daughter. Sekerema recalled thinking as a child, "Yeah. I'm going to be this cool girl in Computer Science. You know, I'll be the only girl and I can represent and I'd feel so cool." Sekerema could easily see that science and engineering had few women, but that made the field even more attractive her then; she wanted to challenge the gender order.

A bit later on, Sekerema fell in love with the piano, a passion that seemed incommensurable with engineering because her parents were not convinced that she could make a living playing piano, and because they saw piano as diverting her interests away from a career that would be able to provide food for her. Sekerema spoke about the disparate nature of piano and engineering:

"When I was 11, I started piano lessons and I didn't want to, but then by the time I was 16 I really liked it. I was going to pursue a degree in that or at least pursue the interest but my parents were like, "That doesn't make any money, so maybe you should go back to your interest in engineering." So I chose engineering [because it was a] field that didn't require too much chemistry, since I'm not too much of a lover of chemistry... and I like math."

When it was time for Sekerema to pick a college, she applied to schools that seemed like "long shots," universities like Stanford and MIT. She applied to schools that were familiar: one 
because her father had attended, and another because a neighbor went there. On the flip side, there were schools that actively recruited her, which made Sekerema feel valued. She also was recruited by a school in South Carolina, who even promised a financial aid package to fund her education. But, the legacy of racism in the state made Sekerema feel unsure about her status there, and she did not reply.

Eventually, Sekerema chose RSU because their recruitment program convinced Sekerema that she would be welcome at the school, and because she wanted to get out of Texas and see the world. She received no financial aid from the school directly, but was able to afford the out-ofstate tuition with help from her father and federal grants. Her father's assistance always carried with it the stipulation that Sekerema concentrate on engineering. This carried implications on her love of piano, which her parents saw as a distraction.

A feeling of isolation on many fronts marked Sekerema's time at RSU. While, the engineering school's multicultural engineering program initially welcomed her, she found that she stuck out because there were not many students like her, who were Black AND women AND had a common background. She struggled to find others who "looked like her," but managed to find a fellow student who was a black woman, whose parents were also immigrants, who eventually became her best friend.

Despite feeling at first isolated within the multicultural engineering program, Sekerema described the program's resources and assistance as reasons she was able to excel her first couple of years in the engineering program. Eventually, the program helped her feel part of a community, too. But eventually she was no longer able to get the help she needed for the more advanced courses in her third and fourth years, and her grades started to slide.

As she progressed through engineering, her struggles with school became her main concern, and her academic life boiled down to passing her coursework so that she could continue to be able to play piano. Sekerema's slipping grades began to alienate her from her own personal goals and even her family. For example, Sekerema became alienated from her original goal that she had when she entered RSU: to learn engineering in a way where she could help the environment. Her priorities shifted to become only grade-oriented. Sekerema began performing two lives to the two important groups in her life because of her poor grades: In one version of her life, the one she told her parents, everything was okay, while in the second version, the real version, she struggled to find motivation to even study, because she hated it so much. Of course, the second version was not shared with her parents, but only with other minority students living out the same struggle who were keen to this narrative. Sekerema's solace throughout her struggles became that at least there were other students in the multicultural engineering program struggling along with her.

Sekerema's strategy to improve her grades displayed her knowledge of how to manipulate the policies of institutions in her favor. In one semester, Sekerema decided to take 25 credits of coursework that she was confident she would get As in to improve her GPA, and hid this decision from her parents, who would surely have disapproved. Sekerema decided to do this because she had come to believe that having good grades would, in a way, show that she was doing okay in engineering, both to her parents and to other employers who she saw as also only caring about the final GPA. By taking 25 credits of anything, her GPA would be boosted, and 
she hoped that the higher number would serve as proof that her experience in engineering education was going well.

Incredibly, Sekerema made Dean's List that semester, but her amazing feat seemed diminished in her mind, perhaps because of feeling shame that none of the coursework was done within the College of Engineering, the program she had worked so hard only to struggle in, or because of the shame that she did all this in secret from her parents, who she thought might have separated her from her piano if they had found out. By this time, Sekerema was lying about the amount of time she spent practicing piano to her parents, because again, she knew they would have disapproved. Sekerema felt she had to lie about her piano practice, because it connected her to something that she loved; something engineering had stopped doing. Engineering had become a means to an end to her, something that would allow her to do something else that she loved, a strategy that worked as long she could hide her struggles.

Through her time at RSU, Sekerema became keen towards the racial order she observed around her and she used it to theorize her own isolation in engineering classes. Furthermore, she seemed to use these observations to define what room she had to act within, but she also did not accept it as the way it had to be. For instance, in describing the racial division within the engineering body, Sekerema said:

"I guess it's the location of the school but it's in the middle of [an Eastern state] and there's some students there, there's some residents of [this Eastern State] that have ever seen any sort of color students ever... so maybe in like my English class as a freshman, I would sit down and maybe I'd sit down maybe 3 chairs over would be like a White guy maybe and it someone would come in which would be a White student they would go and skip over me and sit next to the stranger... the other stranger, White person. I mean, anybody would do that but I was already far away from home and I felt alone from the [minority engineering program] students already so I felt like, 'Man, this is icing on the cake. I should just go back home.' But at least I also felt like I was there showing them that there are colored students here and, you know, we don't bite and... ah... you know, I'm happy to meet anybody and I try to be friendly and I was trying, I guess, to represent other minority students as we're friendly too and we're nice. We're not going to bite or fight you."

In this short story, Sekerema shows she is cognizant of a racial order, one she felt enacted upon her, yet at the same time she was unable or unwilling to name what she felt.

Sekerema's awareness of the implications of her current situation was quite salient at the time of her interview. She recognized her dilemma that her strategy of only caring about grades had created for her as she now neared graduation. Sekerema realized that her concentration on grades only worked in the institutional setting of RSU. As soon as she left, she would no longer be tied to her grades, but rather to her performance of her job, and her struggles in engineering had destroyed her confidence that she could be a competent engineer. She related her impending dilemma to her current moral dilemma, where she had chosen to compromise her own ideals to fit into the ideals others held for her. She struggled to reconcile her actions with her own morality, by alluding to how fake she would feel in future job interviews as she would try to convince her potential employers that she, indeed, actually liked doing engineering. 
Despite her academic and moral struggles, at the end of her interview, Sekerema still connected herself to the idea of change in engineering that she originally held as a child. She positioned herself as a resource for other minority students, both through RSU's minority engineering program, and through NSBE. She hoped that through her guidance, she could help others like her more readily face the struggles she faced in school.

Sekerema's story illustrates the role of intersectionality in forming unique experiences for students. In relation to Sekerema, the intersection of race, gender, and her parents' status as immigrants created an identity that made it hard for her to relate to others, even when she was amongst other Black or women students. Almost immediately upon entering into college, Sekerema felt isolated, even though she was part of a multi-cultural engineering group that was supposed to help her feel included. Sekerema's identification as being Black AND a woman AND the child of immigrant parents was something that the program could not account for. She struggled to find others who looked like her and shared the same family background and experiences.

The intersectionality of Sekerema's identity also fed into her idea of "the right way to live." One influence on her morality was carrying out the wishes of her parents. Sekerema's wanted to honor the wishes of her parents, whose own hopes for her may have been related to their background as Nigerian immigrants. Sekerema struggled to live up to the morality that had been socialized into her by her parents, a struggle that other children of immigrant parents might identify with as well. Her parents' beliefs that she should work in a field where employment and income would not be a worry for her became a goal for herself. Sekerema's inability to live up to that goal became a source of shame, and after reviewing the interview, we wondered if part of the reason she told the story was that she sought forgiveness for not being able to do what her parents had dreamed for her, and, even moreso, forgiveness for her lying to them about it.

Another influence on Sekerema's morality was due to her identification as a Black woman, and here, too, the intersectionality of identity factors in greatly. This identification affected her experience within engineering, from her original desire to enter into the field, to how she chose RSU, her experience of isolation within RSU's College of Engineering, and lastly, as a leader in her school's NSBE group. At times in the interview, her experience of a situation seemed due to her identification as a woman, like when Sekerema mentioned that she wanted to become an engineer to affect the gender order she saw immediately present as a child. At another time in the interview, she described her experience of being a Black student isolated from her primarily White peers in the classroom. But, at another time in the interview, Sekerema directly described how the intersectionality of both being Black AND a woman isolated her, ironically, within the very program that was supposed to connect her with other historically isolated students: RSU's multi-cultural engineering program. Through all these situations, Sekerema struggled to resolve the self-doubt that resulted from trying to figure out the right way to proceed given the identity she saw herself as.

After listening to her experience, we were struck by Sekerema's experience of being graded and it's relation to the intersectionality of her life. Sekerema's perception of being graded conflicted with the intersectionality of her identity, and in turn, her sense of morality related to that identity. For instance, getting high marks supplanted Sekerema's ethic of being honest with her parents, 
and was a source of shame in her life. In another instance, the desire to receive high marks also replaced her desire to be an engineer that helped the environment, another source of shame. Finally, the hope for high marks, and her struggles to receive them, superceded Sekerema's own sense of self-worth, making her question what her place was in engineering. We came to think that, even if Sekerema had received high grades in engineering, that this result would still have only masked the truth of her situation (that she did not really like engineering) and that she still would not have seen herself being successful as a professional engineer. As a result, we wondered how can educational institutions better facilitate students like Sekerema to make use of all their talents, and not just the ones that grades highlight, to help guide them through not just the curriculum of a plan of study, but also, within their own personal goals for engineering? Sekerema clearly had many talents, but didn't have opportunity to see them as beneficial in an engineering context as well as the context of her own identity. Grades become her way of seeing herself as an engineer, something that "abstracted" her total abilities. Is it time to take a look at what grades are doing to students that once wished to be engineers?

We now turn to Sammie's case analysis.

\section{Table 7: Case analysis of Sammie}

Sammie is a 25-year-old Black man, a Navy veteran who moved 3 months earlier to Fairbanks, Alaska where his wife is stationed with the Army. He is currently a junior in a mechanical engineering program at the University of Alaska-Fairbanks, having transferred here with a number of credits from various community colleges, paid for through his military benefits.

Sammie grew up in Lansing, MI in a poor family. His mother worked very hard to provide for Sammie and his 5 siblings - four older, and one younger. At different points of Sammie's early life, at least two siblings were in foster care, and by the time Sammie was 14, his oldest sister (who had already been "in and out" of foster care) had had two children, both of whom had been taken by the state and adopted by a family in another state. Sammie described his family members' lives by saying how many kids each of his siblings had, and what partner relationship they may currently be in. The oldest sibling had gotten his GED and was enrolled in community college, the same one Sammie himself started in. Sammie was very close with his father, who died while Sammie was enlisted; some of Sammie's close military friends came to Michigan to support him during this time. Sammie describes these friends as his real "family" and noted they were almost the only people who came to his and his wife's wedding. Sammie's mother is a key character in his story of his enlistment, as he was terrified to tell her he had signed up for the military, the first in his family to do so.

Sammie described his drive for becoming an engineer as being motivated by a family friend and his mentor, who himself was a mechanical engineer at a nearby state university, and whose family took in multiple members of Sammie's family at different crisis points. It was this mentor who encouraged Sammie to enroll in community college, as Sammie's GPA was not high enough for admission at the university. But Sammie has persisted in this goal in order to "put food on the table," believing that "you can go anywhere with a mechanical engineering degree."

Sammie described his decision to enlist in the Navy as one governed by his friend's suggestion - he hadn't been doing too well in his community college courses, and was working 2 jobs on 
top of these, and the friend (and a local recruiter) told Sammie, "You need Life School." Sammie talked about maintaining his goal of getting a formal education throughout his military service: for example, he changed divisions in order to get more support for his taking courses at Tidewater Community College while stationed in Norfolk, VA, and he talked about difficulties taking courses while enlisted, such as being deployed before he could finish the course and thereby missing the final exam, or trying to take courses through Central Texas College which sent instructors to live aboard ship while it was on deployment. While overall Sammie found his military service to have been a good investment for him, he described his problems with staying focused on school in an environment that purportedly supported his efforts but in fact did not, referencing his time in his first division.

Now he is looking forward to getting an internship in the short term, then finishing his bachelor's degree at UAF, and getting a job that pays well; he and his wife are discussing when they want to have children, with his wife more eager than he. His wife also wants to have another wedding, one where her family is able to attend as well as his. But he's on track to graduate, and sees "finding a job... [as going to be] the hardest part."

Sammie's educational career seems to have been buffeted around by where he was enlisted or living at the time - upon discharge, he moved to Texas to live with another friend, and enrolled in Houston Community College, a 2-year community college as it was located nearby, even though his friend was currently enrolled at the University of Houston (a 4-year school with an engineering program). However, community college was good to Sammie through its small classes, and the individual focus and commitment to student learning of its instructors; the only thing it overlooked was the guidance to apply for engineering internships, as HCC's career center didn't help with such matters. However, he's getting this guidance now as a part of his membership in ANSEP at the University of Alaska-Fairbanks, where he now goes to school while his wife serves her term in the Army. He is also getting opportunities to network with prospective employers, which he also didn't have at community college.

Sammie's interpretation of his educational career is governed by his grades - his original GPA prevented him from going to university to start with, his poor grades in community college in Lansing prompted him to enlist in the Navy, his grades he earned while enlisted were fairly dependent on the largess of his instructors' accommodations of his deployment schedule and not on specific institutional policies put in place to support members of the military or veterans from succeeding in their coursework. But his educational career also seems governed by who would accept the credits for the work he had already completed - his transfer from HCC to UAF was complicated (perhaps because it was still recent at the time of our interview) because some courses required by the University of Houston (to which HCC was preparing its students for transfer) were not required by UAF, and the converse. Sammie described the transfer process as "very simple," despite these difficulties.

So Sammie's case is one of a member of the military with little non-military cultural, social or economic capital trying to get an engineering degree by whatever means necessary because of the respect he has for his mentor's advice. He accepts whatever judgment of his performance grades provide, and sees people who help him as going out of their way rather than doing their jobs. 
So, having now presenting these two extensive storied cases, ${ }^{15}$ we offer some thoughts on what this type of analysis helps us now consider with respect to our research questions.

By tracing the voice in step 6 in Sammie's transcript, we began to see that Sammie was describing a particular set of ruling relations whenever talked about "you" and "they." It is the indicator mechanism that he is talking around a ruling relation, or a text of some kind that governs how people operate or work together. For example, he talked about his choice of major: "I mean, you can go anywhere with a mechanical engineering degree," (emphasis added). How does he come to know that an ME degree is somehow more translatable than other disciplines? How does he come to trust that, with an ME degree, he will have value across jobs, that the social order will respect the pedigree of $\mathrm{ME}$ as more flexible than an IE degree? So doing the narrative analysis - looking at how he said things, not just what he said - helps us identify the places to look for the influence of ruling relations.

Ruling relations' theoretical focus on texts prompts us to start to think about what texts govern the social relations that Sammie describes. When he talked about his instructor allowing him to take his final even after final grades had been submitted because Sammie had been deployed during the normal scheduling (an event which did not make it into the storied case in full detail), we ask whether this accommodation was a written policy somewhere that the organization has operationalized, or was it a "workaround" that the instructor implements to accommodate "special cases" like Sammie? How does our noticing other "workarounds" help us to identify how the institution is raced, or gendered? So, for example, if Tidewater Community College had a written policy that accommodated the deployment schedules of military personnel in the administration of final exams or other assignments, then we could begin to see that TCC was an organization inclusive of the military. But if not, then also perhaps not.

In contrast, considering a different set of texts that both Sekerema and Sammie are much preoccupied by, both participants see grades as perhaps representing the culmination of their educational learning and/or as then representing their capacity to be good engineers to future employers. Indeed, one might argue that this is what institutions set grades up to do, that this is the function of grades: to act as inscriptions of courses that function in cross-institutional transactions (employers want to know what students have learned, so universities and colleges produce a grade and claim that this represents what they have learned into a concise, portable, and translatable metric ${ }^{14}$ ). But how do universities help students put grades into perspective in terms of the larger stories of what they have learned? How do universities structure their grading practices around the different lived experiences of their students? We would argue this is very limited; what might it look like if they did?

More overtly, by looking at his story through the lens of the larger institutions that have structured it, we start to wonder how structure and operating procedures of institutions such as Family and Child Services, or the community college systems, or the military, have influenced Sammie's education and his chances at successfully starting an engineering career. How have Sammie's experiences of FCS in his early life (as just "taking" his siblings, or his other relatives) influenced how he expects to be treated by educational institutions in light of his performance (as made manifest by his grades)? How do community colleges or four-year universities structure their admission, regrade, or other attendance-aligned policies to support the education of military 
personnel? How did community colleges' policies of open admission facilitate Sammie's early educational choices, and with what consequences?

Writing the case focuses our attention on how all the pieces fit together. How does the "voice" read help us think about ruling relations that may be opaque to the participant? How does the table of contents make us pay attention to all the different stories, not just the most obvious ones? How does writing out the narrative as a case prompt us to think about the logic of the story and help reveal places where texts as social relations operate, even if the participant isn't aware of it?

Our $9^{\text {th }}$ step of our analysis is to present claims about ruling relations to each other and to colleagues for scrutiny and interrogation. We consider this paper and its associated presentation a contribution to this step.

\section{Conclusion}

We have presented our current research analysis process in much detail here to present to the research community our method and methodology for discussion and scrutiny to help us improve our future practice through a form of strong objectivity. ${ }^{24}$ But we have as yet said little about what all this says about race and gender, let alone how engineering educational institutions are gendered and raced.

This necessitates one remaining step with which we have yet to engage very thoroughly. This step is the production of what Walther and colleagues would call "knowledge claims" in the form of papers proffered for public scrutiny and discussion.

We believe that the storied cases will be useful products to help illustrate how ruling relations structure underrepresented undergraduate engineering students' lives in different ways. But we see that they will need to be situated in larger contexts for us to be able to make claims. For example, considering Sammie's case, we need to understand the demographics of the military, and whether it is skewed towards higher fractions of working class people and of people of color to be able to argue that overlooking the fact of military personnel's imminent deployment as relevant to policies on grades and course completion is a raced and classed decision. Alternatively, we might begin question what engineering programs' responsibilities are to develop ruling relations that work for people that fit outside the archetype of "engineering undergraduate student" - Sammie is married, a veteran, and an alumnus of at least 3 community colleges, but didn't know he needed to get an internship until he joined an organization for Alaska Natives. Or, considering Sekerema's case, we need to better understand how grades might function differently as behavioral determinants for different racial or gender groups.

But in either of these cases, it is not necessary to know that a large fraction of Black women have similar experiences; that is, we do not need to argue Sekerema's experience as "generalizable" to be able to learn from her experience to then move towards designing educational institutions and policies that are inclusive of more types of lives. It is enough to know about Sekerema, and other small numbers of people.

We will soon shift to analyzing new interviews using the analytic process outlined here, although we intend to remain sensitive to the need to adjust the process to maintain or strengthen qualitative validity given new fodder with potentially new characteristics. 
What this paper contributes to the broader discourse, in the end, is an illustration of how to maintain an awareness of the race, class, and gender positionality of the data collector and analyst throughout the analytical process, and how to treat holistically a co-produced transcript of a story to understand larger macro and meso-level structures that have been largely overlooked by the engineering education research community.

\section{Acknowledgements}

We are very grateful to all our participants so far for sharing their stories with us. Thanks to the members of the Research in Feminist Engineering group (RIFE; feministengineering.org), and to Joachim Walther and Nicki Sochacka for their insights into this work. This material is based upon work supported by the National Science Foundation under Grant No. 1055900.

\section{Bibliography}

1. Gibbons, M. T. Engineering by the Numbers. 2010, (2010).

2. Crenshaw, K. Demarginalizing the Intersection of Race and Sex: A Black Feminist Critique of Antidiscrimination Doctrine, Feminist Theory, and Antiracist Politics. Univ. Chic. Leg. Forum (1989).

3. Connell, R. Gender. (Polity Press, 2009).

4. Acker, J. From sex roles to gendered institutions. Contemp. Sociol. 21, 565-569 (1992).

5. Acker, J. in Fem. Found. Towar. Transform. Sociol. (Myers, K. A., Risman, B. J. \& Anderson, C. D.) 299317 (Sage Publications, 1998).

6. Smith, D. E. Institutional Ethnography: A Sociology for People. Gend. Lens (Altamira Press, 2005).

7. Smith, D. E. The Everyday World As Problematic: A Feminist Sociology. Northeast. Ser. Fem. Theory (Northeastern University, 1987).

8. Pawley, A. L. "Learning from small numbers" of underrepresented students' stories: Discussing a method to learn about institutional structure through narrative. in Am. Soc. Eng. Educ. Annu. Conf. Expo. (2013).

9. Omi, M. \& Winant, H. Racial formation in the United States: from the 1960s to the 1990s. (Routledge, 1994).

10. Lucena, J. C. Making Women and Minorities in Science and Engineering for National Purposes in the United States. J. Women Minor. Sci. Eng. 6, 1-31 (2000).

11. Wallace, R. A. \& Wolf, A. Contemporary Sociological Theory: Expanding the Classical Tradition. (Prentice Hall, 1998).

12. Living Apart - ProPublica. at <http://www.propublica.org/series/living-apart>

13. Campbell, M. L. \& Gregor, F. M. Mapping Social Relations: A Primer in Doing Institutional Ethnography. (AltaMira Press, 2004).

14. Roth, W.-M. \& McGinn, M. K. >unDELETE science education:/lives/work/voices. J. Res. Sci. Teach. 35, 399-421 (1998).

15. Polkinghorne, D. E. Narrative configuration in qualitative analysis. Int. J. Qual. Stud. Educ. 8, 5-23 (1995).

16. Dollard, J. Criteria for the life history. (Yale University Press, 1935).

17. Mauthner, N. \& Doucet, A. in Fem. dilemmas Qual. Res. (Ribbens, J. \& Edwards, R.) 119-146 (SAGE Publications Inc., 1998).

18. Clair, R. P., Chapman, P. A. \& Kunkel, A. W. Narrative approaches to raising consciousness about sexual harassment: From research to pedagogy and back again. J. Appl. Commun. Res. 24, 241-259 (1996).

19. Walther, J., Sochacka, N. W. \& Kellam, N. N. Quality in Interpretive Engineering Education Research: Reflections on an Example Study. J. Eng. Educ. 102, 626-659 (2013).

20. Naples, N. A. Feminism and Method: Ethnography, Discourse Analysis, and Activist Research. (Routledge, 2003).

21. Tuhiwai Smith, L. Decolonizing Methodologies: Research and Indigenous Peoples. (Zed Books, 1999).

22. Reinharz, S. Feminist Methods in Social Research. (Oxford University Press, 1992).

23. Miller, J. F. in Unrelat. Kin Race Gend. Women's Pers. Narrat. (Foster, M.) 103-119 (Routledge, 1996).

24. Harding, S. in Fem. Theory A Philos. Anthol. (Cudd, A. E. \& Andreasen, R. O.) (Blackwell Publishers, Inc., 2005). 